\title{
The Dynamics of Traditional Religion in the Political Economy of Ìkòrodú
}

\author{
Adéyẹmí Balógun \\ University of Bayreuth \\ adeyemi_balogun@yahoo.com, yemi.balogun@uni-bayreuth.de
}

\begin{abstract}
In the precolonial period, the coastal town of ìkòrodú played a prominent role in the traffic of goods and services between traders on its coast and many Yorùbá groups who lived in the interior. While this traffic was sustained by socio-political institutions such as the Ọlọjà and the Òșùgbó cult, the role of religious groups - including the Ifá priests, Màgbó, Líwẹ and Agẹmo - remained highly influential because they represent the deities and spirits which shaped İkòrodú's inhabitants' views about social life, economic activities and political institutions. İkòrodú has, however, experienced a transformation from a traditional commercial economy into an urban center with modern industrial firms and capital infrastructures. The town has also witnessed the emergence of Muslim and Christian groups, and socio-ethnic groups from many parts of Nigeria. This transformation has not only challenged the authority of the traditional institutions in Ikòrodú, it has also impacted on the religious beliefs and practices which underpin the socio-economic and political systems of the people. A notable example is the reduction in dates of religious festivals which Traditionalists believe were once instrumental in sustaining social order and prosperity in the town. The power of the state has also affected the responsibilities of the Traditionalists in the town. This article further shows how this transformation has shaped relations between religious groups and the state in İkòrodú.
\end{abstract}

\section{Introduction}

In spite of the impact of social change resulting from the adoption of Islam and Christianity in the nineteenth and twentieth century - as well as the influence of modernization, urbanization and the colonial and postcolonial state on 
traditional communities in Africa - several studies suggest that traditional religious practices and the institutions which uphold them have survived in many African communities. ${ }^{1}$ The way and manner they have survived varies from one community to another. In İkòrodú, a coastal Yorùbá community in Lagos State, it is possible to identify a number of traditional religious practices and institutions that survived these forces of social change. These include the socio-political group called the Òsùgbó, which used to be the highest legislative body in the town before the emergence of the modern state system. There are also religious groups who are custodians of Ifá divination, and of the Màgbó, Líwẹ̀, Agẹmọ, Ẹlúkú, Egúngún, and İgunnukó masquerades, among others, as well as traditional medicine practitioners. These dominated life in the town before Islam and Christianity were introduced. However, despite large-scale conversion to Islam and Christianity, many İkòrodú citizens patronize traditional religious groups to find solutions to personal and communal problems.

Overall, the pattern of social change in İkòrodú shows that traditional religion has survived not merely because it remains associated with extraordinary power, but also because of several factors, including its ability to adapt to new ideas and values. For instance, Traditionalists in the town remain important for important civic functions such as the installation of a ruler, and they continue to offer an important service to many townspeople who are Muslims or Christians. Moreover, they have adjusted their dates of festivals to avoid clashes with those of other religions. As will be discussed below, the state has shown some ambivalence in its relation with the Traditionalists; it has limited the powers of its opponents by punishing those who disturb the celebration of Traditionalists' festivals, including those who violate embargoes on going out during certain celebrations.

Given these various factors, this article argues that Traditional religion in modern İkòrodú can be understood within the context of the complex and dynamic nature of the forces of social change which have transformed the town from a rural community to a center of trade and eventually into an urbanized center that is part of greater Lagos. The article adopts a historical methodological approach and it explores the nature of Traditional religion in the political-economy of İkòrodú in the precolonial period before discussing the major factors that have shaped the practice of this religion up to the present times. The article further illustrates the ambivalent nature of Traditional religious institutions in modern İkòrodú.

1. J. K. Olúpọnà, ed., African Traditional Religions in Contemporary Society (Michigan: International Religious Foundation, 1991); E.D. Thomas, African Traditional Religion in the Modern World (Virginia: McFarland and University of Virginia, 2005); J. O. Awólàlú, "What is African Traditional Religion," Studies in Comparative Religion, 10.2 (1976): 1-10. 


\section{Early history of Ìkòrodú}

İkòrodú is located in the northwest of Lagos in south-western Nigeria. Like Lagos, Epe and Badagry, it was involved in the trans-Atlantic trade in the pre-colonial period. Sources on the early formation of the town remain inadequate and often contradictory. There are conflicting claims about the prince from İjệbú-Rẹ́mọ, the western district of the former İjẹbú kingdom, who was said to have founded İkòrodú. Some accounts point to either Lásùwọ́n and Sẹkúmádé or Akàrígbò (now the paramount ruler of Rẹ́mọ) himself, while others credit Ọgà, who was a wealthy farmer, as the founder of the town. ${ }^{3}$ Despite the link to Ijẹ̣bú-Rẹ́mọ, and Ijjệbú more generally, Ọládùnjoyè suggests that İkòrodú was also occupied by Awori and Benin groups. ${ }^{4}$ Even so, İkòrodú maintained a familial relation with the Akàrígbò of İjẹbú-Rẹ́mọ land for many years after its establishment, probably in the seventeenth century.

The first Akàrígbò in Rẹ́mọ was said to be a prince called Kọ́nyẹ̀lú or Kọ́yẹ̀lú, who led a group from Rẹ́mọ quarters in Ile-Ife to settle at Orílé-Ọfin (now Sàgámù) in about the seventh century. ${ }^{5}$ Some historical accounts of İkòrodú also maintained that the Rẹmọ and Benin groups formed a socio-political system in which the leader of the Benin party called Eregbouwa assumed the position of Olisa (kingmaker), while a Rẹmọ prince named Lasunwon became the Olọjà in about $1630 .{ }^{6}$ In spite of this local alliance with Benin, the Akàrígbò continued to be recognized as a supreme authority over İkòrodú.

A body known as the İwàrệa (six chiefs) also assisted in the administration of İkòrodú. The council which included the Agbọn of İṣẹlẹ̀, the Baálẹ of Àga and the Jagun of İjòmù is headed by the Olisa. ${ }^{7}$ Members of the İwàrệfà are also part of the Òsùgbó cult charged with both legislative and judicial functions. ${ }^{8}$ Olúwo is the administrative head of the Òsùgbó. While the sources on the early history

2. O. S. Oládùnjoyè, "A Political History of İkòrodú from the 17th Century to 1894," Unpublished M. A. thesis, University of Lagos, Lagos (Nigeria) 1986.

3. O. Ayọddélé, History of Remo: Thirty-Three Traditional Towns, Migration to 2008 (Ṣagámù: Olu Ayọ̀délé Printers, 2008); O.E. Peters, “İkòrodú from Earliest Times to 1999," Unpublished BA Essay, University of Lagos, Lagos (Nigeria), 2008, 18.

4. Oládùnjoyè, "A Political History of İkòrodú".

5. Ayọ̣délé, History of Remọ; O.M. Daré, “Trade and Religion in İkòrodú,” Unpublished BA Essay, University of Lagos, Lagos (Nigeria), 1982.

6. "İkòrodú in Brief", İkòrodú Oga Association, UK (IOAUK). Accessed 22 August, 2013, http://www.ikoroduoga.net/history.html; Association of 'Korodu Descendant Union. AKDUSA.ORG. Accessed online November 14th, 2016, http://www.akdusa.org/home. aspx.

7. H.O. Ọnáfowókàn, and M.O. Awódẹindé, "Òșugbó was brought to İkòrodú by the first Olisa," Oríwù Sun, July 1990, 2.

8. Daré, "Trade and Religion". 
of the town remain scanty, this political set-up seems to have been maintained until the colonial period. Most accounts are silent on the history of the Benin group after state formation. What is mostly known is that İkòrodú began to have a commercial relationship with Benin after Eregbouwa arrived. ${ }^{9}$ Similarly, there is not much information on the social history, the pattern of settlement and the development of the economy of the people until the nineteenth century.

Nonetheless, the early history of the town shows that people settled in three major areas, namely Àga and İjòmù, İsẹẹ̀ẹ, now known as the traditional quarters. They engaged in farming, fishing and hunting, and traded in slaves, palm oil, and fire arms, among other products. ${ }^{10}$ This led to the rise of some markets such as Fàlàwọ́ market formerly at the present Àyángbùrẹn's palace, Ébùté market at Ébùté-İpakòdó (port), and İwọrò market at Àjíná, close to a former royal palace. These markets were the hubs used by the people in their role as middlemen between traders bringing goods from Lagos to the port of İkòrodú where they were exchanged with goods produced by Yorùbá groups in the interior. Among those who traded with İkòrodú were İjẹbú-Rẹmọ towns such as İpẹ́ru-Rẹ́mọ and İpara, as well as traders from Ẹgbá and İbàdàn. ${ }^{11}$ Due to its position in the flow of trade from Lagos to other Yorùbá groups, İkòrodú developed a strong economic relationship with Lagos. ${ }^{12}$

In 1862, İkòrodú was designated as a British protectorate and it came under the authority of the Colony of Lagos following its liberation from a siege by the Abẹòuuta army in $1865 .{ }^{13}$ The liberation of the town re-opened İkòrodú to trade with Lagosian and British traders, which had been disrupted by the siege. Although the actual annexation of İkòrodú did not take place until the 1890s, the interest of Lagos helped to reduce the influence of the Akàrígbò in Rẹmọ, and of the İjẹbú kingdom more generally, over İkòrodú. ${ }^{14}$ Under one of Glover's successors, Governor Carter (1891-7), İkòrodú was eventually formally annexed and formed into a separate District under Lagosian control in 1894. ${ }^{15}$ While Rẹmọ was included into this district in 1898, it was removed

9. B. A. Agírí, “Lagos- Ìkòrodú Relations 1894-1950," in Ade Adefuye et al, eds., History of the Peoples of Lagos State (Lagos: Lantern, 1992).

10. Oládùnjoyè, "A Political History of İkòrodú".

11. Daré, “Trade and Religion," 21-22.

12. Agírí, "Lagos- Ìkòrodú Relations," 197-207.

13. E. Philips, “The Egba at İkòrodú, 1865: Perfidious Lagos?” African Historical Studies, 3.1 (1970): 23-35.

14. I. Nolte, Obafemi Awolowo and the Making of Remo: The Local Politics of a Nigerian Nationalist (Edinburgh: Edinburgh University Press for the International Africa Institute, 2009), 131-132.

15. T. Oduwobi, İjẹbú under Colonial Rule 1892-1960: An Administrative and Political Analysis (Lagos: First Academic Publishers, 2004): 38-44. 
from Lagos to İjẹbú-Òde District (later Province in 1921) after 1914. ${ }^{16}$ The administrative separation from both İjệbú-Òde and İjẹbú-Rẹmọ under British rule enabled İkòrodú to develop largely independently of local centers of power, if under colonial control.

\section{Traditional Religion}

Like in many other Yorùbá communities in this period, religion permeates the social, economic and political institutions of İkòrodú. Although the concept of religion was unknown to practitioners at the time, ${ }^{17}$ the phenomena that are related to it in modern terms are rooted in their social relations and worldview. The concept of religion is a modern development which is often naturalized in western scholarship, and what is understood as religion has remained largely controversial in literature. Geertz attempted to define it as a system of symbols which establish a powerful and pervasive mood that helped to formulate ideas of existence, which are legitimized in concepts with a sense of factuality that makes them real. ${ }^{18}$ However, this perception has been criticized by such scholars as Talal Asad for being too universalist. ${ }^{19}$ He questions many of Geertz's arguments and challenges the idea that symbols must necessarily produce religious dispositions in people. The various arguments that have been raised on what religion is have inspired Smith's argument that religion is an illusion because it is a concept reified by people. ${ }^{20} \mathrm{He}$ is also of the view that 'religion' has been confused with 'the religious', which involves such practices as rituals, praying, and making sacrifice. In spite of these controversies, the concept of religion has continued to be used as a tool of analysis in literature and as a category which relates to phenomena such as belief in Supreme Being, veneration of deities and ancestral worship. While it would be anachronistic to suggest that Yorùbá speakers had a clear notion of some traditional practices as religious and others as secular, I use the term religion to

16. Nolte, Obafemi Awolowo and the Making of Remo, 146-147; T. Oduwobi, "Deposed Rulers under the Colonial Regime in Nigeria: The Careers of Akarigbo Oyebajo and Awujale Adenuga (Dirigeants déchus sous le régime colonial au Nigeria: La carrière del'Akarigbo Oyebajo et de l'Awujale Adenuga)," Cahiers d'Études Africaines, (EHESS), 43.171 (2003): 554 .

17. J.D.Y. Peel, Religious Encounter and the Making of the Yorùbá (Bloomington, IN: University Press, 2003).

18. Clifford Geertz, "Religion as a cultural system," in Clifford Geertz, The Interpretation of Cultures: Selected Essays (London: Fontana Press, 1993), 87-125.

19. Talal Asad, "The Idea of an Anthropology of Islam", Occasional Papers Series, Washington: Center for Contemporary Arab Studies, 1986.

20. W. C. Smith, The Meaning and End of Religion (San Francisco: Harper \& Row, 1978). 
refer to those traditional practices which are, from the vantage point of the present, understood as religious.

I have mostly discussed the traditional religious traditions of the people of İkòrodú in the pre-colonial period in the present tense. A major reason for this is that most of these religious traditions continue to be observed in modern times, albeit with some modifications. A fundamental belief in the Traditional religion of the people of İkòrodú is the existence of a supernatural Supreme Being called Olódùmarè whom they believe can be reached through a number of spirits and deities called Òrìnà (divinities). A popular belief in Yorùbá theology is that these divinities have the attributes of the Supreme Being, and could be regarded as God's children. According to Idowu, it is also believed that these divinities are the ministers and functionaries of Olódùmarè in a theocratic government of the universe. ${ }^{21}$ Because they are considered relevant in their relationship with Olódùmarè, they are believed to play important roles in what happens to individuals and the community as a whole. Ôrìsà are believed to be responsible for peace, security, prosperity and taking away epidemics from the town. They may be called upon in times of personal and communal conflicts with real and perceived enemies. Many deities, such as Ògún and Egúngún, are similar to deities that can be found in other Yorùbá communities such as Oyo, Ife, Ekiti, Abẹòkúta and İléșà. However, İkòrodú has many other deities which are more specific to other İjẹbú and Rẹ́mọ groups, such as Màgbó (Orò is also widely celebrated in the Ẹgbá settlements west of Rẹmọ), Líwẹ, Ẹlúkú, and Agẹmọ.

The performance of rituals associated with Màgbó is believed to drive away evil forces away from the town. The festival usually commences with sacrifices offered at the Orò grove. During the day, Màgbó priests and other devotees move around the town with songs. Màgbó Orò has one Pákọ masquerade, ${ }^{22}$ which is usually brought from the nearby town of Ogijo. In the night, the Pákọ moves around the town with a roaring sound. Men can follow it, but women are forbidden to be out during the performance of this ritual in the night. ${ }^{23}$ Those who violate this order are said to be punished by death or banished from town. It was only in the colonial period that the government stopped the Traditionalists from imposing such punishment. ${ }^{24}$ However, as will be shown later, women have important roles to play in the organization and performance of festivals in İkòrodú.

21. E. B. Idowu, African Traditional Religion: A Definition (London: SCM Press Ltd, 1973), 62.

22. This is an Orò devotee with an effigy which symbolizes the spirit of Màgbó.

23. Interview with Roslam, in Jaiyesinmi Street İkòrodú, January 7, 2017.

24. Daré, “Trade and Religion," 11. 
Màgbó Orò festival is closely related to Líwẹ Orò. This relationship could be linked to their common source of origin as both are said to have been introduced to İkòrodú by an Ègbá woman who married an İkòrodú man. ${ }^{25}$ Líwẹ̀ is normally performed seventeenth days after Màgbó and celebrations of both deities are held on a market day called ọbún òkè. ${ }^{26}$ Furthermore, Màgbó followers reside in the İjòmù area of İkòrodú, which is a neighboring community to İṣẹlẹ̀ where the Líwẹ̀ followers are resident. Líwẹ̀ has sixteen Pákọ̀ which are taken from Itọ́wólò. ${ }^{27}$ However, Líwẹ is believed to be an ancestral spirit that helps to eliminate any form of epidemic such as leprosy, measles and chicken pox. Líwẹ may also be called upon to help settle quarrels between wives especially those in polygamous families, and it is held together with Èỳtà festival in honor of the Ọlọjà. ${ }^{28}$

Èlúkú is said to be related to another powerful deity called Agẹmọ, which is believed to have originated from the town Agbowa in İjẹbú. Agẹmọ festival is expected to precede Ėlúkú. The deity is represented with a cylindrical object of about two to three feet. A devotee is expected to carry this object on his head in addition to putting on reeds around his body. In İkòrodú, women are barred from seeing Agẹmọ. Those who violate the rule are believed to be cursed by Agẹmọ, and this could result in mental disability or bodily harm. ${ }^{29}$ But women are expected to offer supplication to the deity after seven days of procession and ritual activities around the town. It is believed that Agẹmọas the power to bless people's homes, especially those seeking child-birth and prosperity in trade.

Èlúkú is the most famous deity of İkòrodú for outsiders. The popularity of this deity is noticed in the praise name of the people of İkòrodú who are referred to as children of Ẹlúkú (Ọmọ Ẹlúkú mẹdẹ mẹdẹ). In İkòrodú, the deity is believed to have been introduced from Ile-Ife by Kọnnyẹlú. ${ }^{30}$ The worship of this deity is restricted to male İkòrodú indigenes only. The festival associated with it follows a similar pattern as Màgbó and Líwẹ̀. It begins with sacrificial offerings at the Ẹlúkú grove, followed by a procession of devotees around town singing and praising Ẹlúkú. It is not expected to come out during Ébùté and İwọrò market days. ${ }^{31}$ Ẹlúkú is believed to be a benevolent spirit. One of its most important

25. Ibid.

26. Interview with Baálè A. Abayomi, a Chief in Sabo Ìkòrodú, October 4, 2016.

27. Interview with Roslam.

28. Daré, “Trade and Religion," 10-14.

29. Ibid., 14

30. For an extensive discussion of Ẹlúkú, see Insa Nolte, "Colonial Politics and Precolonial History: Everyday Knowledge, Genre, and Truth in a Yoruba town," History in Africa, 40.1 (2013), 1-40.

31. Interview with Roslam. 
functions is to pray for the well-being of the town. However, it is also believed to be capable of inflicting punishments on those who wrong others. ${ }^{32}$

In spite of restricting their movement in the nights, women are actively involved in the performance of many festivals in İkòrodú. During the Orò festival, women called Ámbașu are responsible for dressing the İya Orò (the chief Orò). But they are not permitted to enter the Orò grove with the men. ${ }^{33}$ Also, in the public ceremonies of traditional festivals, women are expected to be seated with other traditional chiefs. Apart from this, there is a popular Òrìsà called Ọta whose chief custodian is a priestess called İyalóde Ọta in Itúnmọja İkòrodú. Ọta is considered to be a woman. Ọta River (Odo Ọta or Odo Alagbafọ) at Itúnmoja is believed to be the symbol of this deity. Before Eyibi (Agẹmọ and Ẹlúkú) festival is fixed, İyalóde Ọta and other women devotees are expected to perform some rituals which include a ceremonial sweeping of the town and prayers at Odo Ọta with wọro leaves. ${ }^{34}$

Festivals associated with these deities are not necessarily an annual event. They may also be held on the advice of Ifá when the need arises, for example in times of misfortune or insecurity. ${ }^{35}$ The Ifá oracle is believed to be knowledgeable about the world, and is capable of explaining problems of any kind and their solutions. Ifá may also be consulted by individuals or the community before undertaking any major activities and the procedures that are needed to achieve them. This is necessary in order to seek the favor of deities and spirits who are believed to reside in different spaces, objects and phenomena such as the environment, markets, earth, trees, rivers, thunder and iron. Deities and spirits are also believed to reside in some human beings perceived as unusual or special, such as kings, twins, albinos, and people with hunchback. ${ }^{36}$ According to Dopamu, spirits are believed to be abstract powers in these entities, and objects which are believed to have spirits may be used to prepare magic and medicine. 'They have real existence and they can be good or bad, beneficent or malevolent. Consequently, they are propitiated out of fear. ${ }^{37}$

In traditional religious practice, the social relations, economic activities and political administration of the people are linked to different religious values

32. Daré, "Trade and Religion," 15-16.

33. Interview with Mr Tajudeen Adésànyà, Orò Chief priest in Aga İkòrodú, January 10, 2017.

34. Interview with Roslam and Abayomi.

35. Interviews with Olúmalè Agẹmọ (Agẹmọ priest), and Chief Adéșẹyẹ Oyesanmi in Igbogbo Market, Igbogbo, October 3, 2016.

36. A. Dộpamu, "The Yorùbá Religious System,” Africa Update, IV.3 (1999); J. S. Eades, The Yoruba Today, (Cambridge: CUP, 1980). Online version at http://lucy.ukc.ac.uk/YorubaT/yt6.html.

37. Dọ̀pamu, "The Yorùbá Religious System”. 
and taboos. In the past, resources such as land could not be sold because it was believed to be owned by the Òrìnà. Today, this is no longer the case as the acquisition of land has been monetized. But even today, people may consult Ifá before settling on the spouse they wish to marry. The intervention of deities may also be required in the settlement of conflict between individuals or groups. Also, before choosing a career in life, people may consult with Ifá. One of my respondents explained that the reason why many people are having challenges in their work today is because of their failure to find out which job is ordained for them by God. ${ }^{38}$ According to him, "some people will be saying that they are just working, they don't live a good life, no profit in their market, and so on. But, ask them if they consult Ifá or àlufáà to find out which job is ordained for them." Moreover, some professional groups may be required to worship a particular deity who is believed to symbolize the tools they use for their trade. This included hunters and ironsmiths who worship Ògún, the deity of iron.

The administration of the town also requires the support of the deities. While the ruler (or Ọlọjà) and the Òṣùgbó must ensure that commercial activities and social relations are conducted properly, this often requires that they consult with Ifá or the deities in the discharge of their duties. The Olọjà and the Òsùgbó cult are highly revered. The Ọlọjà is considered to be sacred because he is believed to be the second-in-command to the gods. Like in many Yorùbá kingdoms, he is not expected to be seen in public every day. During festivals, he is required to pray and offer gifts to the deities in order to bring prosperity to the town. ${ }^{39}$

The extent to which religion functioned in determining the social, economic and political administration in precolonial İkòrodú is not known in detail, and it is not likely that people's beliefs and practices remained static before the arrival of Christianity and Islam. Trade and marriage especially brought new Òrìsà and ideas into the town, and some of them were adopted locally and included into the İkòrodú pantheon. Traditional practices were further modified following the introduction of Islam and Christianity, and the imposition of colonial rule in the nineteenth and twentieth century. New practices and religions influenced Òrìnà worship also because they resonated with pre-existing ones. ${ }^{40}$ For example, the former Ọ̣̀ni of Ilé-Ifẹ̀, Ọba Adesoji Aderemi, emphasized the similarity in traditional and Christian values by pointing to the

38. Interview with Dele Shokẹyẹ, Màgbó priest in İjòmù İkòrodú, October 4, 2016.

39. O. S. Oliyide, "The Introduction and Development of Islam in İkòrodú," Unpublished BA Essay, University of Lagos, Lagos (Nigeria), 2006, 2.

40. Anonymous, "Wole Soyinka on Yorùbá Religion: A conversation with Ulli Beier" in Isokan Yorùbá Magazine, III.III (1997). 
shared emphasis on a mother's sacrifice for the greater good in the celebration of Mọ́remí (in Ilé-Ifệ) and the story of the Biblical Mary, mother of Jesus. The next section of the article looks at the trends that influenced religious change in İkòrodú.

\section{Religious change in Ìkòrodú}

Islam and Christianity are the two main religions that have impacted on how traditional religious beliefs and practices in Îkòrodú are experienced. Little is known about the early introduction of Islam into the town. Dare's study suggests that the religion may have been introduced in the mid-nineteenth century at the time of the Ėgbá-İkòrodú war (Àgbàlé war) of $1865 .{ }^{41}$ The influence of Islam may have grown in the town when more than a hundred Muslim Hausa police were stationed at Îkòrodú to dislodge the Ẹgbá forces during the Àgbàlé war. ${ }^{42}$ The role of Hausa Muslim slaves, many of whom were captured in the wars in which İkòrodú and its warriors were involved, and later used as servants, may also have contributed to the growth of Islam in the town.

The growth of Islam in İkòrodú is also attributed to a Nupe Mallam called Alfa Tairu, who is said to have been invited to prepare charms for the İkòrodú army against the Ėgbá in the Àgbàlé war. While living in the town, he was joined by his sons, one of them, Ganiyu, marrying an İkòrodú woman. ${ }^{43}$ One Aliyu who arrived in İkòrodú before 1860 as a trader and cleric is also credited with having introduced the religion to the town. Little is known about Aliyu's origin, but there are suggestions that he was either an İlorin or a Hausa man who formerly lived in İjẹbú-Òde before moving to İkòrodú. He built a small hut in the Itúnmoja area of the town where he prayed with his family and later attracted other Muslims. In the 1920s, the number of Muslims in the town greatly increased because many Muslim clerics came to live in the town from Kabba, Îlorin, and Iseyin. Many of them established Quranic schools and became Imams of different mosques in the town. ${ }^{44}$

These early Muslims did not find it easy to propagate Islam when they arrived as many people in İkòrodú held firmly to their tradition. When Islam was new to the town, the Muslims found it difficult to practice their religion in the open. Gradually, a few of them accepted the new faith, and some of the converts were quite bold in the condemnation of the people's tradition. Among them was Alhaji Alifat Mustapha who was notorious for publicly denouncing

\footnotetext{
41. Daré, “Trade and Religion," 40-42.

42. Ibid.

43. Ibid.

44. Oliyide, "The Introduction and Development of Islam in İkòrodú," 13-14.
} 
those who mixed Islam with traditional practices. ${ }^{45} \mathrm{He}$ also clashed with members of the Agẹmọ cult who forbade him from constructing a "storey building" in Itúnmọja near the Agẹmọ shrine. ${ }^{46} \mathrm{He}$ earned for himself the title, 'Ajágbe mọ́ kèfèrí for his intolerance towards syncretic practices of Muslims and the practices of non-Muslims. Alhaji Mustapha's harsh tones reflected the treatment of Muslims by some Traditionalists.

Early Muslims were sometimes beaten up or mocked, especially when the celebration of their festivals clashed with those of the Traditionalists. This happened during the celebration of the Muslim Eid festival in 1944 when members of the Traditionalists dressed as Muslims to pray at a separate Eid ground at Ota Ona along İkòrodú-Isin road while the Muslims were having their own at the designated site at old İkòrodú-Șàgámù road. After the prayers of the pretenders, they returned to the house of the Balogun of İkòrodú, Chief Mábadéjẹ Jáiyésimi dancing and singing “Ti Màgbó la ó șe, Ti Ànábì la ó șe” (We will worship Màgbó, we will worship Ànábì at the same time). A petition was addressed by the Chief Imam of İkòrodú to the Commissioner of the Colony who helped to resolve the matter that year. ${ }^{47}$ Apart from this incidence, Òsùgbó cult members were also said to have clashed with Muslims over several traditionally sacred or important sites chosen by Muslims to build mosques for prayer.

Several factors may have been responsible for the growth of Islam in the town. One of these was the growing importance of commercial relations with Muslim traders, which encouraged many to become friends with Muslims and to provide mutual help for each other. Many were also inspired by the ability of certain mallams to provide charms for personal problems. The influence of Muslim clerics who embarked on public preaching also encouraged many conversions to the religion. The role of Muslim organizations that arrived in the town by the 1930s was also significant in this growth. The major ones were the Ansar-Ud-Deen Society, Shamsudeen Society, and the Ahmadiyya Muslim Jama'at who provided both Western and Islamic education for Muslim children in ways that naturalized Islam as a religion of progress in İkòrodú. ${ }^{48}$ İkòrodú witnessed the emergence of several other Muslim groups in the post-colonial period, notably the Alásàlátù groups or praying societies includ-

45. In 1926, Alhaji Mustapha founded a Muslim organization called the Ansarullah Society of İkòrodú which became instrumental in promoting mutual support among Muslims in the town (Daré, "Trade and Religion," 44-5).

46. A storey building is the Nigerian expression for a house with more than one storey or floor.

47. National Archives of Nigeria at Ibadan (NAI), COMCOL, 758.1, Mohammedan Festivals. İkòrodú, December 2, 1944. [JP: Not sure how to read this - what are NAI and $\mathrm{COMCOL}-$ is this a periodical?]

48. Daré, “Trade and Religion," 50. 
ing the Nasrul Lahi-li-Fathi Society (NASFAT), Quareeb, and the Samadani movement. These groups have been able to increase their membership not only because of the message of Islam they preached, but also because they provide a range of socio-economic and welfare activities for their members, such as small scale loans for businesses.

In spite of the early challenges to Islam, Christianity had a more difficult start in İkòrodú. The religion had made inroads in places like Igbesa, Sagamu and İkòrodú by 1854, following the advice of Henry Townsend to Church Missionary Society (CMS) agents not to focus only on Abẹòuúta for evangelization. The missionaries were able to record some success when they obtained the support of Ọlọjà Òdúbọ̀tẹ̀, likely on the throne only slightly after this period, and Balogun Jáiyésimi. ${ }^{49}$ The Christian message failed to appeal to many because the missionaries insisted that people abandon their traditional beliefs and practices before they could be welcomed into the Christian faith. They also criticized such practices as polygamy and slavery which could be found in the homes of many people in the town. As a result, the Christian missionaries faced stiff opposition from groups such as the Agẹmọ, Egúngún and Òșùgbó cults, and they also clashed with Muslim clerics who saw them as a challenge to their space in the town.

However, Christian missionaries were able to bring the people of İkòrodú into their faith through education. Due to its special relationship with Lagos, many in İkòrodú began to appreciate the role of education in providing access to European lifestyle and employment in the colonial service. Many people enrolled into the missions' schools which usually at that time insisted on conversion into Christianity. But while many Muslim children converted, others, such as Chief Sule Oyeshola Gbàdàmọ́sí, who will be referred to later, reconverted into Islam once they had completed their education. As mentioned above, several Muslim groups later responded to the challenge of missionary schools by providing modern Muslim schools, which often provided both Western and Islamic education.

A number of Traditionalists also began to associate with Christianity in the town. They found a platform to do this in an independent church movement called the African Church of Bethel, founded in 1914. ${ }^{50}$ Unlike the mission churches, the African Church of Bethel did not force its members to abandon all of their traditional practices. Members of African Bethel could remain in the Òsùgbó cult while attending church, and they were also permitted to marry more than one wife. Other churches that are more open to African ideas and practices include the Christ Apostolic Church (CAC), the Celestial Church of Christ

49. Ibid., 51-53.

50. Ibid., 55 . 
(CCC), as well as Cherubim and Seraphim. An example of this could be found in the revelation of a pastor of the of the Cherubim and Seraphim Church Alápèrè̀, Kétu and Odógíyán İkòrodú, Solomon Ọládiméjì, who confirmed his membership as the Olúwo of Sálà Ogboni fraternity, and he claimed that the sacrifices he used to heal and pray for people in his church had antecedents in the Bible. ${ }^{51}$

From the 1980s, Christian Pentecostal churches such as Deeper Life Church, Mountain of Fire, and the Redeemed Christian Church have also made inroads into İkòrodú. These churches have been able to gain converts not only due to their Biblical messages, but also due to their emphasis on wealth. In a period of socio-economic crisis which has affected Nigeria since the 1980s, this message appealed to many people in need, a trend which is also noticed in many African countries. ${ }^{52}$ More importantly, these churches have also made many believe that the socio-economic and spiritual problems they undergo in life are a result of the kind of traditional practices which their parents and relatives indulged in. However, while they try to persuade their followers to abandon traditional religion, Pentecostalism has largely remained relevant because many people could relate to many aspects of its doctrines and practices. ${ }^{53}$

In addition to education, Christianity was attractive because of its association with the superior material culture of the British colonial rulers. According to Nyang ${ }^{54}$, the impact of the material culture of Europeans in social change in Africa has been overwhelming because the way Africans saw them confounded and challenged local beliefs and technologies. As many Yorùbá people considered European culture to be sign of prosperity and progress in life, they turned to Christianity as a way of becoming part of this culture.

\section{Political, economic and social change in Ìkòrodú}

The incorporation of Ìkòrodú into the British colonial administrative system in 1894 was the main factor in a radical transformation of the political

51. “'I belong to Ogboni confraternity and CAN' - Lagos Pastor confesses," The Herald (2014), accessed online November 13th 2016, http://www.herald.ng/belong-ogboni-confraternity-can-lagos-pastor-confesses/.

52. Ogbu Kalu, African Pentecostalism (New York: Oxford University Press, 2008), 183; Mbe, A.R. "New Pentecostalism in the wake of Economic Crisis in Cameroon," Nordic Journal of African Studies, 11.3 2002: 359-376.

53. Ogbu Kalu, African Pentecostalism, 183; L. Jarrison, "Pentecostal Doctrines, Beliefs, Practices and African Traditional Religion," Augustine Research Fellowship, 2015. [JP: http://arfellowship.com/pentecostal-doctrines-beliefs-practices-and-african-traditional-religion/ accessed here?]

54. S. S. Nyang, Religion and Social Change in Contemporary Africa (Washington: Howard University, 2010). 
institutions of the town. This began with the recognition which Governor Carter gave to Balogun Jáiyésimi, an influential war leader during the İkòrodú-Ègbá war, against the Ọba of İkòrodú. Although Carter later recognized that this was a mistake, he continued to disregard the Olọjà who was the acknowledged ruler of the town. In 1901, the British established a Central Native Council which was made up of Balogun Jáiyésimi, the Ọlọjà and two other chiefs. The council had no real powers over the administration of the town. It was more like a debating society placed under the District Commissioner located in Șàgámù. This administrative change reduced the influence and duties of the Òsùgbó cult which used to assist the Olọjà in the administration of the town. İkòrodú also had a Resident Officer and police detachment which further limited the Òsùgbó council's executive and judicial powers. ${ }^{55}$

After the demise of Balogun Jáiyésimi, the Ọlọjà regained some prestige when his title was elevated to that of the Àyángbùrẹ́n in 1937. By 1938, he gained more power when the British changed the local government administration which revived the traditional political system. ${ }^{56}$ Between the high colonial period and independence, however, the powers of traditional political institutions across the country declined as a new and modern political elite emerged. However, especially in the Yorùbá-speaking parts of Nigeria, the ties between traditional rulers and politicians remained close, and while military rule in the 1960s and 1970s often excluded Obas, they continue to play important advisory roles today. In İkòrodú, the Àyángbùrẹ́n is today under the authority of İkòrodú Local Government.

While the formal creation of the Ikorodu District in 1894 strengthened economic relations between İkòrodú and Lagos, it further led to a number of economic developments in İkòrodú. ${ }^{57}$ This included the establishment of a botanical garden in 1897 to facilitate the growth of cash crops such as cocoa, coffee, rubber and kola. The need to transport these cash crops and other goods encouraged the growth of motor boat services between İkòrodú and Lagos. Notable among these were those of Mr Joshua Ricketts and Mr Ọșínúbi for the Owólòwó Company. İkòrodú also witnessed the rise of many businessmen who plied their trade between Lagos and İkòrodú. This includes the Kamson brothers who established textile industries along Adéníji Adélé, Isọlọ and Àkọkà. The increase in commercial activities provided employment for many people in İkòrodú, and it attracted new migrants to the town. It was through incoming businessmen, as well as wealthy İkòrodú citizens living in Lagos,

55. Agírí, "Lagos- İkòrodú Relations," 202.

56. Ibid., 202-3.

57. E.O. Akeredolu-Ale, "A Sociohistorical Study of the Development of Entrepreneurship among the İjẹbú of Western Nigeria." African Studies Review, 16.3 (1973): 347-364. 
that new ideas and socio-economic development flowed back into İkòrodú. ${ }^{58}$ Wealthy Lagos migrants used their wealth to build schools like Oríwù College and contributed to the construction of a road linking İkòrodú to Lagos. The completion of this road in 1953 and the introduction of electricity in 1956 encouraged further transformation in the town. ${ }^{59}$

By the end of the twentieth century, Ìkòrodú had witnessed the rise of other major businesses. The establishment of an industrial estate in the town encouraged the emergence of big factories such as $\mathrm{PZ}$ who manufacture home products, Nichemtex which specializes in textiles, and modern banking institutions such as Union Bank, First Bank and Guaranty Trust Bank. The Lagos State Government's initiatives to support the growth of small scale industries and alleviate poverty from the 1980s have also created a number of opportunities for many people, including the building of the biggest shopping complex in the town called Ayangburen market. As part of efforts to reduce bottlenecks on the Lagos-İkòrodú road, the state government also revived the ferry transport service at Ébùté-Ipakodo to aid the movement of people traveling between Lagos and İkòrodú across the lagoon. Besides the ferry system, the Federal government of Nigeria also reconstructed the port at Ébùté to ease congestion at Apapa port. The transformation witnessed at this port has led to a drastic reduction in the traditional market activities at Ébùté.

For many years, the political and economic change in İkòrodú continued to reflect in the careers of several people in the town, notably Chief Sule Oyeshola Gbàdàmọ́sí and Òtúnba Theophilus Shobowale Benson, who were actively involved in the development of the town and national politics. Gbàdàmọ́sí, ${ }^{60}$ the Ọtún of İkòrodú and one of the leading industrialists in Yorùbáland at the time, was elected a member of the Western Region Assembly and Federal

58. Ibid., 204-6.

59. IOAUK.

60. After working with a German company, Karl Stark Limited, he partnered with his cousin Rabiu Ayinla Allison under the name İkòrodú Trading Company (ITC). The company specializes in the importation of goods and manufacturing of singlets and ceramics. His activism in Nigerian politics began when he joined the Nigerian Youth Movement which had other young Nigerian nationalists at the time such as Ayo Vaughan, Ernest Ikoli, Samuel Akinsanya, H.O. Davies, Nnamdi Azikiwe and Obafemi Awolowo. He went on to become a member of the Egbẹ Omo Oduduwa in 1946, a pan- Yorùbá cultural group which was used to create a sense of nationalism among the Yorùbá of southwest Nigeria from the mid-1940s (C.A. Alade, "Sule Oyeshola Gbàdàmọ́sí, 1910-1993: A Study in Grassroot and National Leadership." in Siyan Oyeweso and M.O. Raheemson, eds., Actors and Institutions in the Development of Islam in Lagos State (Ibadan: Matrixcy Books, 2013), 563-597). 
House of Representatives. ${ }^{61}$ Benson, ${ }^{62}$ on the other hand, trained as a lawyer and went on to become Nigeria's first Minister of Information, Broadcasting and Culture in $1959 .{ }^{63}$ In addition, the gradual urbanization of İkòrodú continued to facilitate the growth of the population of the town. Coming from different parts of the country and other parts of Lagos, many people found employment in modern industries or joined the informal market sector. However, the economy was not the only pull factor; the high cost of living or building houses in Lagos further contributed to the push. This has expanded the borders of İkòrodú beyond its main traditional quarters from İṣẹ̀lẹ̀, İjòmù and Aga to areas such as Igbogbo, Gbẹ̀rígbẹ̀, Elẹ̣pẹ̀, İjẹdẹ, Àgùrá, and Àgbọ́wá, some of which were formerly separate settlements. Population increase has also encouraged the development of more road networks, and the provision of social amenities such as electricity, schools, hospitals and pipe-borne water. But on the negative side, the increase of population has led to higher rates of crime and unemployment, to bottlenecks in access to major facilities such as water and health care, and to traffic congestion. The dynamics and complexities of this socio-political and economic change have affected traditional religious beliefs and practices in İkòrodú in different ways. Not only did Traditionalists in the town believe that İkòrodú has changed, there are many people in the town who also expect that Traditionalists should adjust their traditional practices to make room for them.

\section{Traditional religion in a time of social change}

In the light of social change caused by the emergence of new religious movements and modernization, Traditionalists in İkòrodú have been made to adjust their cultural practices, often times, by incorporating new ideas and dropping old ones. Many of them think that this is inevitable because 'everything has changed, and we are now in the time of civilization' ('gbo gbo nnkan ti yí padà, ayé ọ̀làjú la wà). ${ }^{64}$ As in the case of Rệmọ, where Nolte discovered

61. Alade, "Sule Oyeshola Gbàdàmọ́sí".

62. He started as a public servant in the Customs before proceeding to study law in London in 1943. By 1947 when he had qualified as the first lawyer in İkòrodúhe joined the National Council of Nigeria and Cameroun (NCNC) to launched his bid in national politics. He was elected into Lagos Town Council in 1950, and between 1950 and 1965, was elected twice as a member of the House of Representatives.

63. "Nigeria's 1st Minister of Information, T.O.S Benson is Dead at 90," Sahara Reporters, February 12, 2008, accessed 15 Nov. 2016, http://saharareporters.com/2008/02/12/nigerias-1st-minister-information-tos-benson-dead-90.

64. Interviews with Olúmalè Agẹmọ and Baálẹ Abayomi. 
that the introduction of western literacy and monotheism engendered changes in local traditional practice, ${ }^{65}$ a similar experience occurred in İkòrodú. In spite of this, Traditionalists in İkòrodú have ensured that the core of their beliefs and social practices remained intact.

The Traditionalists have adapted to the growing involvement of the state administration in İkòrodú affairs. For instance, in the precolonial era, they were the major institution responsible for the installation of new rulers. Ifá was consulted to help in the selection of a candidate, and the chosen candidate was sanctioned by the Òsùgbó. However, this changed under colonial rule, because the British wanted to ensure that newly installed rulers could fulfil the role they were assigned under Indirect Rule. Today the state government (and, in cases of disputes to the throne, the state judicial system) plays an important role in the election of the new Oba. The state government gives the Oba a certificate and a staff of office when he is to be enthroned in a public ceremony. In spite this official recognition, the Traditionalists insist that the certification by government remains invalid until Ifá has been consulted to determine the proper candidate for the throne. Furthermore, after government has done its own public ceremonies, the traditional prayers, rituals and sacrifices will still be offered during a period of seclusion of the new king. ${ }^{66}$

Moreover, the conversion from Traditional religion to Islam and Christianity also transformed the royal houses of İkòrodú. As a result, the stool of the Àyángbùrẹ́n has been occupied by either a Christian or a Muslim Ọba for most of the twentieth century. But in spite of this, the rulers of İkòrodú have continued to perform ritual duties that are required of them by the Traditionalists. Upon their demise, the Traditionalists also carry out the necessary ceremonies to bid the Oba farewell, which are crucial for ensuring the successful reign of the incoming ruler. If the Oba was a Muslim before his death, the Muslim community prays for him before his final burial ceremony, and if he was a Christian, that responsibility is taken by the Christian community. However, the final burial ceremonies are carried out by the Traditionalists, usually in secrecy. In 2014, following the demise of the Muslim former Àyángbùrẹ́n, Ọba Salaudeen Oyèfúsi, at a London hospital, an Islamic funeral was out of the question. The Traditionalists went to the airport to receive his body insisting that the king belongs to the Òsùgbó, the highest traditional institution, and they are the ones to oversee the burial rites of the late Kábíyèsí, meaning ruler. ${ }^{67}$ Therefore, it is not often made public how, where and when the king is

65. Nolte, Obafemi Awolowo and the Making of Remo.

66. Interview with Olúmalẹ Agẹmọ.

67. E. Ebhomele \& D. Okùnọlá, "İkòrodú Monarch's Corpse Arrives Lagos., PM News (2014). http://www.pmnewsnigeria.com/2014/08/04/ikorodu-monarchs-corpse-arrives-lagos. 
being buried (or if he is buried at all). The annual festivals used to offer prayers for the town, and the worship of deities and ancestral spirits have continued to be observed by the Traditionalists. However, a number of changes have been made to these festivals. The Màgbó festival, for instance, which used to be held for three days, has been reduced to one day. The one-day period has been carefully selected to avoid being on a Friday, when Muslims attend Jumat service, or on a Sunday, when Christians will be in church. Líwẹ festival, which is held seventeen days after Màgbó, is also put into consideration when picking the date for Màgbó. For the most part, the dates of these festivals have either been Wednesdays or Saturdays. The Traditionalists in İkòrodú have worked out these dates in their annual calendar. The calendar is also designed to ensure that festival dates do not fall into the month of Ramadhan for Muslims, and Christmas for Christians. One of my respondents explained that the Traditionalists ask leaders of the Christian and Muslim communities for the possible dates of their annual festivals to avoid clashes. ${ }^{68}$

However, the experience in Ipokia (Ogun State) in 2016 suggests that the agreement between Traditionalists and their Christian and Muslim co-religionists on this date might break down. In Ipokia, a public holiday was declared to mark the Muslim Eid al-Kabir (Iléyá) festival for two days while the Traditionalists had imposed a three-day curfew to celebrate their own festival within the same period, despite a law banning such act by the Traditionalists in the state. To avoid conflict, the Muslim community met with leaders of the Orò group who were said to have agreed to relax the restriction order for them to attend the Eid prayer. In spite of this, members of the Orò group still came out to enforce the curfew order, preventing Muslims from attending the Eid as well as attacking Christians who were out for street evangelism. ${ }^{69}$

In spite of their adjustment, the Traditionalists have not changed the practice of barring women from walking in the night during these festivals, especially between 7 p.m. and 6 a.m. This hour has not been convenient for many women, especially those who come home in the night and leave very early in the morning for work in order to avoid traffic congestion..$^{70}$ It is, therefore, in this restriction of movement that the Traditionalists have continued to be criticized by Christians and Muslims as well as in many national dailies. A Christian cleric who complained about the restriction order in 2016 is of the opinion that this practice is against the "spirit of the country's unity" while his Muslim co-reli-

68. Interview with Chief Sunday Amusa Bánjókò, Màgbó priest, October 4, 2016, İjòmù, İkòrodú.

69. "Eid-el-Kabir: Three arrested as Oro worshippers attack Muslims, Christians in Ogun," The Nation, September, 2016.

70. "Stop Oro Festival, İkòrodú Residents cry out," The Vanguard, September 27, 2011. 
gionist believed that the practice is "anti-democratic and would not allow development and urbanisation to thrive". "Writing earlier in 2008 for the Nation newspaper, Fasure contended that traditional practice which restricts people's movement is 'barbaric' and wondered why in this age of modernity, a community is holding on to such traditions. ${ }^{72}$ This criticism illustrates contemporary biases against Traditional religion, but it also reveals the extent to which Traditionalist festivals are tolerated by Muslims and Christians in İkòrodú.

While the criticisms from Christians and Muslims have failed to stop traditional festivals in İkòrodú, this has happened in the mid-1990s when the traditionalists were confronted within the İkòrodú traditional council. At this time the Èlúkú festival was banned by Ọba Oyèfúsi. Although my respondents were uncertain or unwilling to speak about what really happened in this case, they confirmed that it was a clash revolving around power and the personalities of Ọba Oyèfúsi and the Olúmalẹ (chief priest) of Ẹlúkú deity. ${ }^{73}$ Owing to this, Ẹlúkú festival was not held in İkòrodú for a period of sixteen years until the Ọba passed away in 2014..$^{74}$ According to my respondent, the Oba reserves the power to impose such a ban because he is regarded as the owner of the town and a sovereign over all things within his domain, 'Ọba ba lé ori ohun gbogbo ni.' ${ }^{75}$

Traditional religion has also survived because it is tied to the economic interests of many people, including Christians and Muslims. There are many transporters and mechanical engineers in the town who patronize Ògún, whom they consider a powerful protective force of their trade despite their Muslim or Christian identity. There are also traders who consult Traditionalists when they experience low sales or misfortune in their markets. In any of these cases, the Traditionalists are invited to perform rituals and pray in the market. $^{76}$

The importance of traditional practice is illustrated by the wares sold at the İwọrò market at Àjíná, which continues to attract large number of customers buying items that are mostly used by Traditionalists in the preparation of medicines and charms. During my visit to the market, I discovered that the sellers

71. "AK Clerics in Lagos kicks against Restriction of Movement," The Pioneer Newspaper, May 18, 2016.

72. S. Fásùrè, "The menace of Oro and other traditional groups," The Nation, May 19, 2008.

73. Interviews with Roslam and Adésànyà.

74. One of my respondents claimed it was fourteen years. He further explained that the Ayangburen was annoyed during this period because his Olori (wife) was harassed by the Èlúkú cult in the night when women were forbidden to be out.

75. Interview with Roslam.

76. Interview with Olúmalẹ Agẹmọ. 
of these items, like those who buy them, are either Christians or Muslims, who nevertheless have adequate knowledge of the uses of their charms and are able to prescribe their usage to customers. My respondents confirmed to me that many people also patronize Traditionalists for personal problems in İkòrodú. ${ }^{77}$ There are women who visit them for problems relating to child birth and marriage. Many Muslim or Christian women are seen paying homage and praying to deities during the annual festivals of Agẹmọ and Ẹlúkú. Therefore, the Traditionalists retain social relevance because many people have sustained faith in the efficacy of ancestral deities in addition to their Christian or Muslim beliefs.

However, even though many people use traditional cures, not many wish to be Traditionalist priests or diviners. As a result, it has not been easy for the Traditionalists to sustain their own numbers. To safeguard succession, many ensure that one of their children is initiated into their cult or belief. One of them pointed out to me that some Traditionalists have been able to do this through the socialization of their children from young age. This involves taking a chosen child to attend regular meetings and ceremonies of the group or cult one belongs to. ${ }^{78}$ With this socialization, it is believed that children will not only understand what they are doing and take up the practice, but that they will also be able to counter any negative views about a particular cult when confronted with it from outside.

Apart from socialization, the Traditionalists have tried to draw Muslims and Christians of noble birth into their fold through chieftaincy titles. However, at one point this led to crisis between the traditionalists and members of the other religions. While the traditionalists believed they were acting responsibly by ensuring that chieftaincy lineages are preserved, their rival religionists usually refused to accept this argument because they reject the rituals and traditional practices which are associated with those titles. Owing to this, Oba Oyèfúsi stopped the traditionalists from pressuring Christians and Muslims into accepting chieftaincy titles. The present Àyángbùrện, Ọba Kabir Adéwalé Sotobi, has sustained this ban. However, in spite of his Muslim identity, he benefitted from taking the chieftaincy title of Odofin which facilitated his own enthronement in $2015 .{ }^{79}$ Lagos State recognizes many of the herbal medicines administered by Traditionalists. It also established the Lagos Traditional Medicine Board which regulates the practice of traditional medicine and registers traditional medicine practitioners in the State. Among them are Traditional Birth Attendants (TBAs) and bone setters. ${ }^{80}$ Despite the efforts of the government to

77. Ibid.

78. Interview with Chief Banjoko.

79. Interview with Roslam.

80. This is a local term used to refer to traditional orthopedic practitioners. 
improve the health facilities in the state, the patronage enjoyed by these practitioners remained strong because they are socially acceptable and more affordable. ${ }^{81}$ The experience of many pregnant women in İkòrodú, like in other Lagos communities, also shows that this could be due to non-availability of primary health centers in the night and lack of trust in the medical facilities in these centers. In contrast, the TBAs boast of such medicines as abíwẹ́rẹ (give birth easily) which they administer to pregnant women to make their foetuses small and allow them to deliver babies easily. ${ }^{82}$ In 2014, Lagos state recorded 23,229 deliveries and 23,500 live births through TBAs. İkòrodú topped the list with 4,059 deliveries through 134 TBAs. The figures were lower in 2015, with only 14,536 deliveries recorded through TBAs. The low figure does not suggest loss of faith in TBAs by the people; rather it was largely attributed to non-reporting and non-renewal of licenses by the TBAs for that year. ${ }^{83}$ But, the experience of those who develop complications in the traditional process shows that traditional techniques are not infallible. The effort of the government has therefore been geared towards proper monitoring of the Traditionalists, and towards ensuring that Traditionalists refer patients with complicated health problems to General Hospitals which are located in many local government areas of the state. $^{84}$

Patients may also be referred by hospitals to the TBAs. Some of my respondents explained to me that women with complicated pregnancies or a history of difficult births are usually referred by hospitals to TBAs if they are not willing to go through a Caesarean section. Among these are cases of babies who are wrongly positioned in the womb before delivery. The TBAs are said to have different tools that can be used to correct this and ensure that the baby is delivered without Caesarean. ${ }^{85}$ Indeed, the patronage enjoyed by TBAs in such cases has been boosted by the belief of many people that such complications of pregnancy are caused by 'evil forces' which are perceived to be in several places, including one's family and community, and which (Western-trained) doctors alone cannot address. The presence of 'evil forces' is tied to a number of other occurrences which are believed to be 'strange', and have continued to be addressed by Traditionalists in İkòrodú.

81. A. Adélàjà, "Investigation: More pregnant women die as Lagos struggles with poor healthcare," Premium Times, June, 2014, accessed 14 November 2016, http://www.premiumtimesng.com/news/162312-investigation-pregnant-women-die-lagos-struggles-poorhealthcare.html

82. Ibid.

83. W. Oyèbadà, "Lagos TBAs account for over 14,536 deliveries in 2015," The Guardian. February 23, 2016.

84. Ibid.

85. Interviews with Àbáyọ́mí; Adesanya. 
Several phenomena which are considered strange include suicide, a person with hunch-back, a person with leprosy, a person electrocuted to death and a person who died by drowning. Where any of these is known in the town, the Orò cult group mobilizes to bury the corpse according to the rites of the deity which is believed to be responsible for this occurrence. The death of an electrocuted person, for instance, is believed to be caused by Sàngó (the deity of fire). Consequently, Sàngó must be propitiated before this corpse is buried. ${ }^{86}$ However, in spite of the efforts of the Orò group to ensure that these cases do not escape their attention, several people who have adopted Christianity and Islam have buried such corpses in secret. ${ }^{87}$ Indeed, the ability of the Orò group to sustain their relevance in attending to 'strange' phenomena is dependent on their knowledge of them.

There have been cases where government's support for the Traditionalists was questioned by both Christian and Muslim groups. In 1977, for instance, Nigeria hosted the second World Black and African Festival of Arts and Culture (FESTAC) to showcase its cultural heritage and those of other people of Black Africa. ${ }^{88}$ Traditionalists in Lagos state as well as other parts of the country were allowed to participate at the festival and they were able to initiate some tourists who travelled from the Americas into the worship of Òì̀à in Lagos. ${ }^{89}$ However, while some Christian groups had earlier prayed for the success of the festival, there were others such as members of Jehovah Witness who came to the venue of the festival protesting that the event was a call back to 'primitive' days in Africa. ${ }^{90}$ In spite of this, the government has continued to allow herbal medicines to be displayed during the annual international Trade Fairs held at the Tafawa Balewa Square in Lagos.

However, one of the major challenges faced by Traditionalists is the ambivalence of the state in relation to them. For instance, many Traditionalists believe they have not been recognized appropriately with regards to public holidays. While government approves work free days for Christians and Muslims to mark their festivals, a similar gesture has continued to elude the Traditionalists. Omọotọ̣sọ Ėlúyẹmí, who expressed the need for this holiday in 1993 in a national daily contended that this discriminatory and lopsided treatment is

86. Interview with Adesanya.

87. Interview with Alhaji 'Wasaba', Entrepreneur. 10th January, 2017. Aga İkòrodú.

88. J. Odafe, "Ifá Oracle: FESTAC Produces Three Converts," The Nigerian Observer, January 20, 1977, 1.

89. Ibid.

90. C. Okwuwa, "Preachers Invade FESTAC Venues for Jesus Christ: Festac-a call back primitivity," The Nigerian Observer, January 15, 1977, 16; "Begins Today: All World Blacks meet in Lagos," The Nigerian Observer, January 15, 1977. 
unfair in a democratic and multi-religious society. ${ }^{91}$ However, the Lagos state government has recently approved a day to acknowledge traditional worship, called İșẹșe Day, to be held annually on August 27, but this is not a holiday. In contrast, Ọṣun State, government approved a work-free day to mark İṣẹse Day, also in August, in 2014.

In interviews and conversation, İkòrodú Traditionalists also complained that they received little or no support from government to celebrate their festivals and to perform the sacrifices that are required to prevent the outbreak of epidemics and insecurity in the town. One of my respondents described many incidences in the town that ought to have led to catastrophe, which was however averted thanks to the spiritual intervention of Traditionalist leaders. Important incidents included the accidents of several vehicles conveying petrol products that did not explode despite losing liters of fuel. ${ }^{92}$

The same respondent also pointed to the ambivalent attitude of the state in dealing with the powers controlled by Traditionalists. For example, in 1990 a bus collapsed on the Itọ́wólò bridge, which claimed the life of many passengers. As part of its public response, government was said to have called on Traditionalists to offer sacrifice to the deities at Majidun River to prevent a recurrence of such incidents. This call was taken up by the town, and later in that period Ọba Salawu Oyèfúsi, the Àyángbùrẹ́n of Ìkòrodú, led many priests and sacrificial offerings to the site of the incident to pray while prayers were also offered at his palace for many days. ${ }^{93}$ It should, however, be noted that the ambivalence of the state towards the Traditionalists is not limited to Lagos; it is a feature of Nigeria's national politics in which Islam and Christianity are privileged over Traditionalist practices and concerns despite the country being a multi-religious society.

\section{Conclusion}

Despite the influence of Islam, Christianity, urbanization and the modern state system, and despite the fact that only few people identify openly with Traditional practices, important Traditional religious beliefs and practices of İkòrodú have survived until today. One reason is that individual Traditionalists have been unable to give up on them, because they consider them efficacious both for the community and for individuals. Certainly, Traditional reli-

91. O. Ėlúyẹmí, “Traditional Religion: A Case for Public Holiday," Nigerian Tribune, July, 1993.

92. Interview with Oyesanmi.

93. "Ìkòrodú Mourns-Oba Oyèfúsi, Chiefs appease the gods," Oriwu Sun, January, 1990. 
gion continues to serve the personal and socio-economic interests of many people in the town, even if some aspects, such as royal succession or the celebration of certain festivals had to be adjusted so as not to inconvenience Muslims and Christians too much.

\section{Bibliography}

Eades, J. S. The Yorùbá Today. Cambridge: CUP, 1980.

Idowu, E. B. African Traditional Religion: A Definition. London: SCM Press Ltd, 1973

Nyang, S. S. Religion and Social Change in Contemporary Africa. Center for African Studies and Research Center.Washington: Howard University, 2010.

Olupona, J. K. ed. African Traditional Religions in Contemporary Society. Michigan: International Religious Foundation, 1991.

Peel, J.D.Y. Christianity, Islam, and Òrịà Religion. Oakland: University of California Press, 2016. 